Chapter 22

\title{
Targeting the Lung: Challenges in Gene Therapy for Cystic Fibrosis
}

\author{
George Kotzamanis, Athanassios Kotsinas, \\ Apostolos Papalois and Vassilis G. Gorgoulis \\ Additional information is available at the end of the chapter \\ http://dx.doi.org/10.5772/52532
}

\section{Introduction}

Cystic Fibrosis (CF) is the most common fatal autosomal recessive genetic disease in the Caucasians with a frequency of approximately 1 in 2500 newborns (Cystic Fibrosis Foundation, http://www.cff.org/). It affects several organs including the lungs, the liver, the pancreas, the sweat glands and the gastrointestinal and reproductive tracts [1]. The most severe complications that finally lead to death are those in the airway epithelium [2]. Continuous secretion of mucus causes blockage of the lungs by thick sputum and also makes the lungs susceptible to secondary bacterial infections. Subsequent inflammatory responses by the immune system damage the lungs and the combination of all these factors leads to cardiac failure and to death [3].

The primary defect at the biochemical level that is responsible for the symptoms in the lung was found to involve cAMP-mediated chloride ion $\left(\mathrm{Cl}^{-}\right)$conductance. Specifically, mutations in the gene that encodes a cAMP-regulated $\mathrm{Cl}^{-}$channel in the apical membrane of epithelial cells are the cause of cystic fibrosis. This gene was identified, cloned and named the Cystic Fibrosis Transmembrane conductance Regulator (CFTR) [4, 5]. Though the exact mechanism of pathogenesis is not fully confirmed, the prevailing theory supports that absence or dramatic decrease in the amount of functional CFTR protein at the airways epithelium results in reduced chloride secretion, increased sodium reabsorption and therefore in insufficient airway luminal fluid due to osmosis [6]. These alterations in the respiratory epithelium subsequently result in deficient mucus clearance which determines chronic cycles of bacterial infections and inflammation [6]. In addition, the formation of thick stationary mucus traps neutrophils that might otherwise clear the infection [7]. 
For several reasons including the easy access to the respiratory tract without any intervention procedures, the cloning and the characterization of the CFTR gene and the expectation that even relatively low levels of expression of the gene may have a therapeutic outcome [8], Cystic Fibrosis became an ideal target for gene therapy and an example for gene therapy of other lung diseases. Indeed, the first gene therapy clinical trials for CF started in 1993 and 29 clinical trials have been conducted since then (http://www.wiley.com/legacy/wileychi/ genmed/clinical/). Several trials have demonstrated gene transfer and transgene expression. In some cases, low levels of transient correction of $\mathrm{Cl}^{-}$ion transport deficiency has been observed but overall, no clinical improvement has been achieved. The histological, immunological and intracellular barriers that exist in the lung have proven to be more difficult to overcome than what was initially thought. The purpose of this chapter is to analyze these barriers and to present the challenges the gene therapist is faced with when targeting the lung for the treatment of $\mathrm{CF}$.

First, the basic histology of the lung will be described so that the reader can identify the potential target cells for CF gene therapy and realize the complexity of the lung structures that the gene transfer agent needs to penetrate in order to reach these target cells.

\section{Basic histology of the lung}

The lung is a complex organ that is divided into the air-conducting portion consisting of the trachea, the bronchi and the bronchioles and the respiratory portion consisting of the alveoli, which is the place of gas exchange (Figure 1).

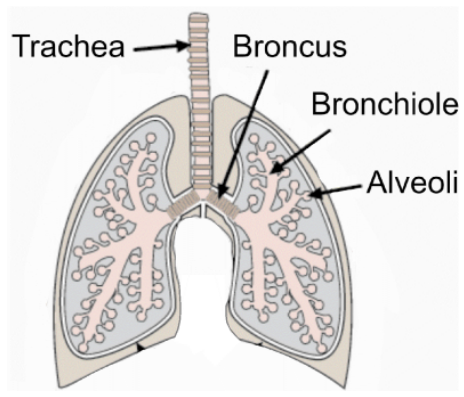

Figure 1. Schematic illustration of the lung.

The trachea and most of the bronchi are covered by pseudostratified columnar ciliated epithelium (known as the respiratory epithelium). Columnar ciliated cells are the predominant population extending from the basal lamina to the airway lumen. Other cells facing the lumen are the nonciliated Goblet cells which produce mucin polymers [9], forming a thin layer of mucus that covers the airway epithelium. The role of the airway mucus is to trap inhaled particles which are then transferred out of the lung by cilia beating and/or cough. The effec- 
tiveness of this action depends on the viscosity of the mucus which is determined by the level of its hydration [10]. Normal airway mucus consists of $97 \%$ water [11] but when luminal fluid is reduced, as in CF, the clearance of mucus by cilia and cough is also reduced. Under the basal lamina lies the lamina propria, which consists of elastic fibers and hosts the submucosal glands that together with the Goblet cells produce components of the mucus [9] (Figure 2A,B,C).

Several stem cells populations responsible for the maintenance of the respiratory epithelium have been identified in the lung. Specifically, a population of basal cells, residing at close proximity to the underlying basal lamina in the larger airways, has been shown to have a high multipotency potential allowing regulation of the epithelium homeostasis under normal circumstances or after injury [12]. Another type of cells with stem-cell-like properties is the Clara cells. These nonciliated cells are located at the terminal bronchioles and produce a solution similar to the surfactant in the alveoli. Interestingly, Clara cells can multiply and differentiate into ciliated cells to regenerate the bronchiolar epithelium [13].

The respiratory portion of each lung consists of approximately 300 million alveoli. Each alveolus has a thin wall consisting mainly of type I and type II alveolar cells (Figure 2D). Type II alveolar cells are responsible for the secretion of a thin layer of fluid that normally coats the alveolar surface in order to decrease the surface tension at the air-fluid interface, the surfactant. Surfactant turnover is mediated by the phagocytic function of alveolar macrophages, which are also located in the alveolar wall and are frequently seen in the alveolar lumen.
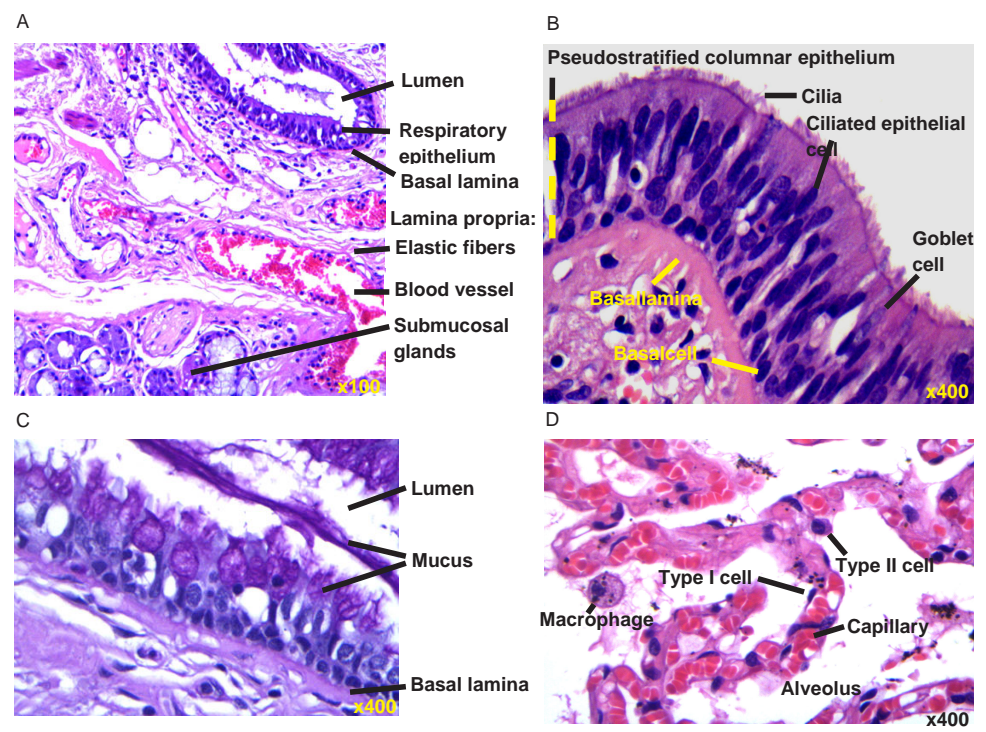

Figure 2. A) Upper respiratory tract section, B) Epithelium of upper respiratory tract, C) Mucus produced in Goblet cells and secreted in the lumen, D) Alveolar section. 
It is not yet clear which of these cells are the target for gene therapy of Cystic Fibrosis. In healthy individuals there is little CFTR expression in the lung, except the submucosal glands and epithelial cells at the small airways where higher expression is observed [14]. Early studies suggested that the submucosal glands are the site of maximal CFTR expression [15], but more recent data suggested that this may be the ciliated surface epithelium of the bronchioles [16]. This uncertainty is one of the main obstacles for successful CF gene therapy. Depending on which are the cells that need to be corrected, different anatomical or immunological barriers apply and therefore different administration methods have to be used.

\section{Physical barriers to gene transfer to the lung}

As most formulations administered to treat $\mathrm{CF}$, including gene transfer agents, are delivered directly to the airways in the form of aerosols [17], the first physical barrier that needs to be overcome before the transgene reaches the target cells is the airways mucus. Trapping in the mucus and clearance by cilia is the main factor reducing transfection efficiency in lung cells of all individuals. In Cystic Fibrosis, the lungs are progressively filled with large amounts of purulent secretions, the sputum, which consists of mucus, DNA, actin, cell debris and inflammatory cells [18]. The most commonly used in gene therapy for $\mathrm{CF}$ viral vectors and non-viral liposomal vectors have been proven unable to penetrate the CF sputum [19, 20], suggesting that effective treatment may be achieved only at early stages of the disease before the lungs are filled with sputum [21]. Several improvements can be made at this stage to increase transfection efficiency, such as use of methylcellulose gel formulations to inhibit mucociliary clearance [22] or of mucolytics $[23,24]$, but these need to be validated in clinical trials.

The second physical barrier to gene transfer to the airway epithelium is the composition of the apical surface of the cells. First, the presence of specific receptors determines the kind of viral vector to be used. For example, adenoviral vectors have low transfection efficiency due to the low abundance of the required receptors on the apical side of most human airway epithelial cells [25] and this is one of the reasons why they are not considered in clinical trials any more [21]. Making the basolateral membrane, which is more abundant in adenoviral receptors [25], accessible to the adenoviral vector has been proposed as an attractive alternative. Indeed, the use of agents such as sodium caprate that can cause transient dissociation of tight junctions, impressively increases transgene delivery and expression in animal models $[26,27]$ but may not have a clinical application due to the risk of systemic bacterial invasion. Second, the glycocalyx on the apical membrane seems to interfere with the interaction between adenovirus and its few receptors [28]. Removal of sialic acid residues from the glycocalyx by pretreatment with neuraminidase may be an effective way to overcome this physical barrier [28].

Although non-viral vectors are not affected by the problems described above, they are subject to possible destruction by the cell defence mechanisms against foreign DNA invasion. 
These mechanisms have evolved to secure the host cell's genetic integrity but in gene therapy they constitute one more hurdle to overcome. Indeed, once the therapeutic DNA enters the target cells in the lung of CF patients, it faces a series of intra-cellular barriers that apply to gene therapy in general and not just to gene therapy for CF. These barriers include degradation by cytosolic nucleases $[29,30]$ and degradation inside digestive lysozomes formed by transformation of endosomes following endocytosis [31]. Several methods have been implemented so that the transgene can escape the endosomes after internalization. Cationic lipids and polycationic polymers like polyethylenimine (PEI) [32] utilised as chemical vectors in complexes with the transfected DNA, protect it from nucleases and enable it to escape the endosomes. Such complexes carrying the CFTR gene have been used to correct the ion transport defect in CF transgenic mice [33] and are currently being tested in clinical practice [34]. Other strategies to protect the therapeutic DNA from the endosomes and therefore to increase the transfection efficiency include the use of pharmacological endosomelytic agents such as chloroquine [35], endosome-disrupting peptides [36-38] and glycerol [39]. All these aim at destabilizing the endosomal membrane so that the contents are released intact to the cytosol but may be of limited clinical value due to safety concerns in the host cells.

The final physical barrier before the CFTR transgene enters the nucleus of the non-dividing airway epithelial cells and undergoes transcription is the nuclear envelope [40]. Many viral vectors can efficiently deliver their cargo in the nucleus by exploiting the nuclear transport systems of the host [41], but non-viral vectors are in most cases ineffective in front of the nuclear envelope. Strategies such as the use of chemical vectors based on PEI [42] and of Nuclear Localization Signals (NLS) which are integrated into the transfected DNA and bind to transporter proteins in order to facilitate nuclear entry $[43,44]$ have been implemented and found to promote nuclear delivery in vitro. However, these have not been validated with large therapeutic genes like the CFTR and in non-dividing cells in vivo and may not be of use for gene therapy for CF [45].

\section{Immunological barriers to gene transfer to the lung}

Apart from the extracellular and intracellular barriers described above, there is a second line of defence consisting of specific and non-specific immune responses that protect the lung cells against foreign particles which are present in the air. During gene therapy for $\mathrm{CF}$, these immunological mechanisms can be activated by the vector carrying the transgene or the product of the transgene and therefore limit the overall efficacy [46].

Various immunological responses are directed against the carrier of the therapeutic gene before this enters the target cells. Pulmonary macrophages have been shown to ingest adenoviral vectors, but when they were removed before transfection, an increase in transgene expression was observed [47]. Furthermore, humoral immune responses mediated by helper $\mathrm{T}$ lymphocytes result in the production of neutralizing antibodies against the vector, which restricts the possibility of re-administration and so, the use of most viral vectors for the treatment of chronic diseases such as CF [46]. 
Other responses are initiated after the transgene is delivered to the lung cells. Particularly when viral vectors are used, cellular immune responses mediated by cytotoxic T lymphocytes eliminate transduced cells expressing viral proteins resulting in parallel loss of transgene expression [46]. Although in theory non-viral vectors are not associated to such problems as they are less immunogenic than viral vectors, in practice they are usually used in combination with ligands so that they overcome the physical barriers described above and this can provoke immunological reactions similar to those caused by viral vectors [46]. In addition, viral and non-viral vectors can provoke the release of host cytokines which have been shown to inhibit expression of the gene delivered if this is driven by a common viral promoter [48].

Several approaches have been developed to overcome the immunological barriers in the lung. The use of immunosuppressant drugs such as cyclophosphamide have been proved very effective in mice allowing both prolonged transgene expression and repeated administration of an adenoviral vector [49]. Similar results were obtained with corticoid steroids such as dexamethasone [50] and budesonide [51] which were found to decrease inflammation mediated by viral vectors. Other strategies include the co-administration of IL-12 [52] and blockade of $\mathrm{CD}^{+} \mathrm{T}$ cells [53-56]. However, all these approaches are likely to cause more damage than benefit, considering that the lungs of $\mathrm{CF}$ patients are colonized by pathogenic bacteria, and so they are not applicable in the clinical setting.

On the other hand, non-viral chemical vectors based on cationic lipids can be re-administered without the need to be combined with immunosuppressants [57]. From that aspect, these are safer than viral vectors for gene therapy of CF but still not absolutely harmless as they have been associated with lung toxicity due to provocation of inflammation [58]. Another mediator of inflammation in the lung can be the CpG motifs on the bacterial plasmid DNA which is usually used to clone the therapeutic gene in non-viral gene therapy $[59,60]$. Unlike eukaryotic DNA, this dinucleotide is relatively unmethylated in bacteria and can be inflammatory through recognition by toll-like receptor 9 on B cells [61]. As methylation of the CpG motifs prior to gene delivery may decrease the expression of the transgene, the exclusion of any bacteria-derived DNA from the therapeutic construct is a more promising alternative.

\section{Safety concerns}

Immunological responses elicited by a gene therapy vector do not only pose a barrier to efficient delivery and expression of the therapeutic gene in the target cells but more importantly, they can raise very serious safety issues. This lesson has been learned from a gene therapy human trial where lethal complications were experienced [62]. In that study, an adenoviral vector containing the cDNA of the gene encoding ornithine transcarbamylase (OTC) was administered to 18 patients with partial OTC deficiency, a disease caused by a defect in urea synthesis. The adenoviral vector provoked immunologic and other side effects, such as fever, myalgia and nausea in 17 out of the 18 participants but the $18^{\text {th }}$ patient developed a 
serious immune response to the vector that eventually led to his death 98 hours after administration [62]. This death was a setback for all gene therapy clinical studies using viral vectors, as human immune responses cannot be predicted pre-clinically. Apart from the immunological responses caused by the vector, other unfortunate events of different nature have also been found to be associated with reduced safety. Treatment of patients with Xlinked severe combined immune deficiency (SCIDX1) using a retroviral vector carrying the $\gamma c$ gene resulted in the correction of the disease and huge enthusiasm about the future of gene therapy [63]. However, two of the cured patients developed a leukemia-like condition 2-3 years later due to disruption of an endogenous oncogene by integration of the vector [64, 65]. Since vector integration is usually random and uncontrollable, insertional mutagenesis is a general problem that all integrating vectors have. As these problems also apply to most vectors used in gene therapy for Cystic Fibrosis, avoiding unwanted immune response and insertional mutagenesis are two major challenges for the genetic treatment of CF. Strategies to respond to the second challenge of insertional mutagenesis will be discussed in the next section. To address the first problem, the solution is to use less immunogenic vectors.

Although adenoviral vectors administered systemically can cause acute and potentially lifethreatening cytokine response [66] their local administration at mild doses to nose and lung tissues did not result in such unacceptable safety profile [34]. However, extensive use of these vectors during the early times of CF gene therapy has shown that cellular and humoral immune responses against the virus are generated and these limit repeated administration $[67,68]$. Another approach to avoid immunologic reactions from the host is to coat the virus capsid with polyethylene glycol (PEG). Such PEGylated viruses, called "stealth viruses", are not recognised by the immune system and can significantly prolong transgene expression [69]. A less immunogenic alternative to adenoviral constructs is the use of adeno-associated virus (AAV) vectors. Indeed, several human CF trials with AAV vectors have confirmed their good safety profile albeit with low transduction efficiency [70-74].

Despite significant progress made towards the generation of safer viral vectors [75], non-viral synthetic vectors containing only human DNA sequences are the vectors of choice when safety is considered as first priority. These vectors generally consist of the therapeutic DNA either naked or mixed with chemical compounds, like cationic lipids or cationic polymers [76]. Naked DNA is in theory the safest gene therapy agent but very difficult to be introduced into the target cells. Several physical methods have been developed to facilitate DNA entry into the lung of living animals, such as the use of electrical pulses (electroporation) [77], of ultrasound waves (sonoporation) [78] and of magnetic fields (magnetofection) [79] but none of them has reached the clinical use yet. On the other hand, chemical carriers have rapidly been developed and used in $6 \%(n=110)$ of gene therapy clinical trials (http:// www.wiley.com/legacy/wileychi/genmed/clinical). These act by forming complexes with the negatively charged DNA. The complexes condense the DNA, protect it from nucleases, allow its entry into the cells and protect it from the endosomes [80]. Indeed, local administration of cationic lipid/CFTR-plasmid-DNA complexes in an aerosol formulation to the lungs of cystic fibrosis transgenic mice resulted in correction of the ion transport defect [33]. Simi- 
lar studies in human patients demonstrated some transgene expression, but not at sufficient levels to provide a clinical benefit [57, 81-86].

\section{Duration of transgene expression}

Provided that all obstacles to gene delivery to the lung are overcome and the CFTR transgene finally reaches the target cells, a clinical benefit for CF can only be achieved by lifelong expression of the gene. As repeated administration is in most cases restricted by immune responses generated by the patient against the vector, other strategies have been employed for efficient retention and long-term expression.

Integration into the host genome has widely been used in gene therapy to fulfil this requirement. However, the dangers of integration due to insertional mutagenesis have become a widely publicised issue as a result of the SCIDX1 clinical trial, where some patients developed leukaemia due to deregulation of the growth-promoting LIM domain only 2 (LMO2) proto-oncogene caused by integration of the vector [64,65]. The safety concerns regarding uncontrolled integration of the therapeutic gene into the host genome have been strengthened by observations that there is a preference of integrating vectors for the regulatory regions of transcriptionally active genes [87]. Given the need for long-term expression and the problems associated with vector integration, vectors that persist in the nucleus by being maintained episomally without integrating, could be highly advantageous. Among the systems developed to achieve extra-chromosomal maintenance of the vectors carrying the therapeutic gene, two are considered safe enough for clinical application in the future: artificial chromosomes and systems based on scaffold/matrix attachment region (S/MAR).

Human Artificial Chromosomes (HACs) are vectors able to replicate and segregate in parallel with the endogenous chromosomes in human cells. To achieve this, they must contain the minimal elements required for chromosome function, namely an origin of replication, telomeres and centromeres [88]. HACs can be generated by a method similar to the one applied for YAC construction in yeast and involves assembling the functional chromosomal elements and building up a HAC de novo in human cells. Different strategies have been followed to generate de novo HACs, the most convenient of which is to transfect a BAC carrying only a large array of $\alpha$-satellite (alphoid) DNA and some marker genes into HT1080 cells[89]. HACs generated this way exist as single (or low copy) chromosomes in the nucleus and have a high mitotic stability (close to $100 \%$ ) in the absence of selection. The potential use of these vectors in gene therapy has been demonstrated by expression of large therapeutic genes from them $[90,91]$.

S/MARs are diverse sequences found in all eukaryotic genomes where they are involved in many aspects of chromatin function such as organization of chromatin into loops, which seems to be mediated by the interaction between S/MARs and the nuclear matrix [92]. Vectors containing an S/MAR element have the ability to remain episomally at low copy number for more than 100 generations in the absence of selection and with a mitotic stability of $98 \%$ [93]. This ability has been demonstrated in several cell lines and in primary cells [94] 
and also in vivo in genetically modified pigs [95] making them very attractive for use in CF clinical trials.

An alternative to the use of episomal vectors described above, that still satisfies both requirements for permanent transgene expression and elimination of genotoxic effects is the controlled integration of the therapeutic DNA at a specific site in the host genome where no active genes are present. Several vector systems have been developed to achieve this, with each one of them having its own limitations [96]. From these, vectors based on the ФС 31 integrase [97] and on transposase enzymes [98] are the most promising for use in CF gene therapy as they have a preference for specific sequences that already exist in the human genome and have been shown to work in vivo.

An additional problem to achieving long-term expression of the CFTR transgene delivered to the lung is the life span of the target cells. Depending on the rhythm of natural turnover of these cells, transgene expression can last for as long as these cells are alive. A more effective approach would be to either target putative stem cells with the capacity to differentiate to airway epithelial cells [34] or to deliver exogenous heterologous or corrected autologous stem cells to the lungs of CF patients ex vivo [99].

Airway basal stem cells are a candidate target for CF stem cell therapy. However, the facts that this population is estimated to represent only a minor part of the total airway epithelium [12] and that it is quite inaccessible as it is not exposed to the airway lumen make such a therapy approach very challenging.

Ex vivo gene therapy using stem cells may not only provide permanent cure without the need for re-administration, but also solve the hurdle of the low in vivo gene delivery efficiency. In ex vivo cell therapy using Embryonic Stem Cells or foetal Mesenchymal Stem Cells from a healthy embryo there is no need for transfection of a therapeutic gene. However, these stem cells are used in an allogeneic fashion which requires the parallel use of immunosuppressive drugs and are therefore not applicable for the treatment of CF. A more attractive strategy would be the transfer of the CFTR gene to patient-derived autologous stem cells such as Mesenchymal Stem Cells (MSCs), which can easily be isolated from the bone marrow or adipose tissue of adults [100] or Induced Pluripotent Stem Cells that can be generated by reprogramming of adult somatic cells [101, 102]. In that case, the transfection procedure would be performed in vitro before reimplantation of the cells back to the donor, which is far more efficient than in vivo delivery. Furthermore, bone marrow-derived MSCs have been shown to be able to express transgenes [103] and to differentiate to several types of cells including airway epithelial cells [104]. Nevertheless, there is little literature on how the ex vivo corrected MSCs can be administered and engrafted in the lung of Cystic Fibrosis patients. Both systemic and topical lung administration of bone marrow-derived cells have been applied and shown to result in some engraftment into the airways [105], but there are several challenges to be addressed, before ex vivo cell therapy becomes part of the CF clinical research. These challenges include the very low efficiency of engraftment $(<1 \%)$ and the fact that previous damage to the surface epithelium caused by epithelia-injuring reagents seems to be required for the engraftment [75]. 


\section{Pattern of transgene expression}

For gene therapy of some diseases it is important to achieve expression of the therapeutic gene at specific levels. Expression at lower levels than normal might not be sufficient to correct the defect and at higher levels could result in undesirable effects. In other cases, tissuespecific expression may be very important. The elements responsible for controlled and tissue-specific expression of a gene usually lie within the introns and the sequences before and after the gene. Therefore, the use of genomic constructs which contain the introns and flanking DNA of the therapeutic gene is expected to be more effective than that of minigene/cDNA constructs in gene therapy for certain genetic diseases where precise levels of the gene product are required [88]. There is evidence that CF is such a disease.

Although some studies have shown that expression of as little as $5-10 \%$ of endogenous CFTR levels may suffice to observe a clinical benefit [106], other studies have shown that different functions of CFTR like $\mathrm{Cl}^{-}$transport and $\mathrm{Na}^{+}$absorption, when they are abnormal they can be restored by different levels of CFTR expression [107]. Moreover, restoration of mucus transport at normal rates requires transduction of at least $25 \%$ of target cells [108]. These data indicate that CF gene therapy may require CFTR expression at the right levels, at the right time and in the right population of cells, which can be achieved only if it is driven and controlled by the gene's natural promoter and regulatory elements present on a genomic therapeutic construct.

The CFTR gene is located on chromosome 7, is 200-250 kb long [5] and comprises 27 exons. It shows a tightly regulated temporal and spatial pattern of expression [109, 110], which was not found to be regulated by any tissue-specific regulatory elements, suggesting that other elements outside the proximal promoter are probably involved in tissue specific regulation of transcription. Several DNase I Hypersensitive Sites (DHS), usually associated with regulation of transcription, have been identified across $400 \mathrm{~kb}$ of DNA flanking the CFTR gene. These lie $5^{\prime}$ to the gene at -79.5 and $-20.9 \mathrm{~kb}$ with respect to the translation start site [111], in introns 1 [112], 2, 3, 10, 16, 17a, 18, 20 and 21 [113] and 3' to the gene at $+5.4,+6.8,+7,+7.4$ and $+15.6 \mathrm{~kb}$ [114]. Most of these DHS have been found to be involved in tissue-specific CFTR expression [114-117]. Therefore, a large genomic construct spanning $\sim 300 \mathrm{~kb}$ from the $-79.5 \mathrm{~kb}$ to the $+15.6 \mathrm{~kb}$ DHS would include all the known long-range controlling elements of the CFTR gene and should give full levels of tissue specific expression which would be advantageous for gene therapy of cystic fibrosis. This big in size region has recently been cloned on a single Bacterial Artificial Chromosome (BAC) vector and is currently available [118].

As the majority of recombinant viruses, commonly utilized as carriers for transfer of plasmid DNA, apart from evoking unwanted immune responses, have a maximum packaging capacity and cannot be used to deliver large genomic-DNA-containing constructs, gene therapy using genomic loci of therapeutic genes should be non-viral. This restriction raises again the issue of efficiency of delivery which is even more challenging to deal with than when using smaller constructs. 


\section{Clinical research for cystic fibrosis}

Gene therapy clinical trials for CF started in 1993 and over 26 viral and non-viral trials have been conducted or are in progress to date. Viral trials were based on engineered adenovirus and adeno-associated virus and non-viral on various cationic lipids, with GL67 being the most predominant. The references for the published studies are listed in Table 1.

\begin{tabular}{lll}
\hline Adenoviral clinical trials & AAV clinical trials & Non-viral clinical trials using cationic lipids \\
\hline Zabner et. al., 1993 [119] & Wagner et. al., 1999 [120] Sorcher et. al., 1994 [121] \\
\hline Crystal et. al., 1994 [122] & Aitken et. al., 2001 [70] & Caplen et. al., 1995 [82] \\
\hline Boucher et. al., 1994 [123] & Wagner et. al., 2002 [74] & Gill et. al., 1997 [83] \\
\hline Knowles et. al., 1995 [124] & Flotte et. al., 2003 [71] & Porteous et. al., 1997 [84] \\
\hline Hay et. al., 1995 [125] & Moss et. al., 2004 [73] & Zabner et. al., 1997 [86] \\
\hline Zabner et. al., 1996 [68] & Moss et. al., 2007 [72] & Alton et. al. 1999 [81] \\
\hline Bellon et. al., 1997 [126] & Hyde et. al., 2000 [57] \\
\hline Harvey et. al., 1999 [67] & & Noone et. al., 2000 [127] \\
\hline Zuckerman et. al., 1999 [128] & & Ruiz et. al., 2001 [85] \\
\hline Joseph et. al., 2001 [129] & & \\
\hline Perricone et. al., 2001 [130] & & \\
\hline
\end{tabular}

Table 1. List of CF gene therapy clinical trials.

The trials have confirmed several of the safety concerns associated to the use of viral vectors. However, other challenges and questions raised pre-clinically still remain to be answered. In general, proof-of-principle for gene transfer to the airways has been demonstrated by transgene expression or partial correction of the $\mathrm{Cl}^{-}$transport defect in some of the trials but clinically meaningful outcomes such as improvement in pulmonary function and decrease of bacterial colonies have not been clearly shown in any. In contrast, poor results with regards to clinical benefit, obtained so far, revealed another challenge in CF clinical research. This is the need to develop more accurate tools to assess gene transfer efficacy at the clinical level [34].

Historically, adenoviral vectors were the first to be used. However, due to the absence of adenoviral receptors on the apical side of most human airway epithelial cells [25], which results in low transduction efficiency, and due to induction of immune responses that exclude repeated administration $[67,68]$, adeno-associated viral vectors became an alternative. These vectors were soon found to have their own problems. First it is their small packaging capacity which barely holds the whole human CFTR gene and therefore restricts the use of strong promoters. Then, at least serotype $2 \mathrm{AAV}$ vectors that were used in initial studies could not be re-administered due to stimulation of immune reactions [72, 73]. Suggestions made to 
overcome these limitations still need to be validated in humans. Non-viral vectors were found compatible with repeated administration [57], but their efficiency were variable and transgene expression was shown only in some studies. In addition, flu-like symptoms were reported [81, 85], which were associated to the presence of unmethylated CpG motifs on the plasmid DNA that was delivered. The use of genomic constructs containing only human DNA may overcome this limitation but this also needs to be shown in future clinical trials.

\section{Conclusion}

Almost 20 years have passed since the beginning of gene therapy trials for CF. Despite initial enthusiasm, only little progress has been made during that time. In contrast, the main conclusion was that the lung is more difficult to target than initially anticipated. Several barriers were discovered, which led to the development of respective ways to overcome them. The majority of these have not reached the level of validation in clinical trials yet. For example, the use of a non-viral vector with the ability to remain extra-chromosomally containing the whole genomic region of the CFTR gene or ex vivo stem cell therapy, are two promising approaches that need to be further explored and may be seen in clinical trials in the future.

\section{Acknowledgements}

AK and VG are financially supported from the European Commission FP7 project INsPiRE. The authors would also like to thank Dr. Ioannis Pateras for his kind gift of Figure 2.

\section{Author details}

George Kotzamanis ${ }^{1}$, Athanassios Kotsinas ${ }^{1}$, Apostolos Papalois ${ }^{2}$ and Vassilis G. Gorgoulis ${ }^{1}$

1 University of Athens, Medical School, Greece

2 Experimental Research Center ELPEN SA, Greece

\section{References}

[1] Grubb BR, Boucher RC. Pathophysiology of gene-targeted mouse models for cystic fibrosis. Physiol Rev 1999;79(1 Suppl):S193-214.

[2] Welsh MJ, Smith JJ. cAMP stimulation of HCO3- secretion across airway epithelia. JOP 2001;2(4 Suppl):291-3. 
[3] Boucher RC. An overview of the pathogenesis of cystic fibrosis lung disease. Adv Drug Deliv Rev 2002;54(11):1359-71.

[4] Riordan JR, Rommens JM, Kerem B, Alon N, Rozmahel R, Grzelczak Z, et al. Identification of the cystic fibrosis gene: cloning and characterization of complementary DNA. Science 1989;245(4922):1066-73.

[5] Rommens JM, Iannuzzi MC, Kerem B, Drumm ML, Melmer G, Dean M, et al. Identification of the cystic fibrosis gene: chromosome walking and jumping. Science 1989;245(4922):1059-65.

[6] Clunes MT, Boucher RC. Cystic Fibrosis: The Mechanisms of Pathogenesis of an Inherited Lung Disorder. Drug Discov Today Dis Mech 2007;4(2):63-72.

[7] Lyczak JB, Cannon CL, Pier GB. Lung infections associated with cystic fibrosis. Clin Microbiol Rev 2002;15(2):194-222.

[8] Dorin JR, Farley R, Webb S, Smith SN, Farini E, Delaney SJ, et al. A demonstration using mouse models that successful gene therapy for cystic fibrosis requires only partial gene correction. Gene Ther 1996;3(9):797-801.

[9] Mrsny RJ. Lessons from nature: "Pathogen-Mimetic" systems for mucosal nano-medicines. Adv Drug Deliv Rev 2009;61(2):172-92.

[10] Lai SK, Wang YY, Wirtz D, Hanes J. Micro- and macrorheology of mucus. Adv Drug Deliv Rev 2009;61(2):86-100.

[11] Cu Y, Saltzman WM. Mathematical modeling of molecular diffusion through mucus. Adv Drug Deliv Rev 2009;61(2):101-14.

[12] Rock JR, Randell SH, Hogan BL. Airway basal stem cells: a perspective on their roles in epithelial homeostasis and remodeling. Dis Model Mech 2010;3(9-10):545-56.

[13] Evans MJ, Cabral-Anderson LJ, Freeman G. Role of the Clara cell in renewal of the bronchiolar epithelium. Lab Invest 1978;38(6):648-53.

[14] Engelhardt JF, Zepeda M, Cohn JA, Yankaskas JR, Wilson JM. Expression of the cystic fibrosis gene in adult human lung. J Clin Invest 1994;93(2):737-49.

[15] Engelhardt JF, Yankaskas JR, Ernst SA, Yang Y, Marino CR, Boucher RC, et al. Submucosal glands are the predominant site of CFTR expression in the human bronchus. Nat Genet 1992;2(3):240-8.

[16] Kreda SM, Mall M, Mengos A, Rochelle L, Yankaskas J, Riordan JR, et al. Characterization of wild-type and deltaF508 cystic fibrosis transmembrane regulator in human respiratory epithelia. Mol Biol Cell 2005;16(5):2154-67.

[17] Proesmans M, Vermeulen F, De Boeck K. What's new in cystic fibrosis? From treating symptoms to correction of the basic defect. Eur J Pediatr 2008 Aug;167(8):839-49.

[18] Rubin BK. Mucus, phlegm, and sputum in cystic fibrosis. Respir Care 2009;54(6): 726-32; discussion 32. 
[19] Hida K, Lai SK, Suk JS, Won SY, Boyle MP, Hanes J. Common gene therapy viral vectors do not efficiently penetrate sputum from cystic fibrosis patients. PLoS One 2011;6(5):e19919.

[20] Sanders NN, Van Rompaey E, De Smedt SC, Demeester J. Structural alterations of gene complexes by cystic fibrosis sputum. Am J Respir Crit Care Med 2001;164(3): 486-93.

[21] Griesenbach U, Geddes DM, Alton EW. Gene therapy for cystic fibrosis: an example for lung gene therapy. Gene Ther 2004;11 Suppl 1:S43-50.

[22] Sinn PL, Shah AJ, Donovan MD, McCray PB, Jr. Viscoelastic gel formulations enhance airway epithelial gene transfer with viral vectors. Am J Respir Cell Mol Biol 2005;32(5):404-10.

[23] Ferrari S, Kitson C, Farley R, Steel R, Marriott C, Parkins DA, et al. Mucus altering agents as adjuncts for nonviral gene transfer to airway epithelium. Gene Ther 2001;8(18):1380-6.

[24] Kushwah R, Oliver JR, Cao H, Hu J. Nacystelyn enhances adenoviral vector-mediated gene delivery to mouse airways. Gene Ther 2007;14(16):1243-8.

[25] Walters RW, Grunst T, Bergelson JM, Finberg RW, Welsh MJ, Zabner J. Basolateral localization of fiber receptors limits adenovirus infection from the apical surface of airway epithelia. J Biol Chem 1999;274(15):10219-26.

[26] Gregory LG, Harbottle RP, Lawrence L, Knapton HJ, Themis M, Coutelle C. Enhancement of adenovirus-mediated gene transfer to the airways by DEAE dextran and sodium caprate in vivo. Mol Ther 2003;7(1):19-26.

[27] Johnson LG, Vanhook MK, Coyne CB, Haykal-Coates N, Gavett SH. Safety and efficiency of modulating paracellular permeability to enhance airway epithelial gene transfer in vivo. Hum Gene Ther 2003;14(8):729-47.

[28] Pickles RJ, Fahrner JA, Petrella JM, Boucher RC, Bergelson JM. Retargeting the coxsackievirus and adenovirus receptor to the apical surface of polarized epithelial cells reveals the glycocalyx as a barrier to adenovirus-mediated gene transfer. J Virol 2000;74(13):6050-7.

[29] Lechardeur D, Sohn KJ, Haardt M, Joshi PB, Monck M, Graham RW, et al. Metabolic instability of plasmid DNA in the cytosol: a potential barrier to gene transfer. Gene Ther 1999;6(4):482-97.

[30] Pollard H, Toumaniantz G, Amos JL, Avet-Loiseau H, Guihard G, Behr JP, et al. Ca2+-sensitive cytosolic nucleases prevent efficient delivery to the nucleus of injected plasmids. J Gene Med 2001;3(2):153-64.

[31] Dean DA, Strong DD, Zimmer WE. Nuclear entry of nonviral vectors. Gene Ther 2005;12(11):881-90. 
[32] Boussif O, Lezoualc'h F, Zanta MA, Mergny MD, Scherman D, Demeneix B, et al. A versatile vector for gene and oligonucleotide transfer into cells in culture and in vivo: polyethylenimine. Proc Natl Acad Sci U S A 1995;92(16):7297-301.

[33] Hyde SC, Gill DR, Higgins CF, Trezise AE, MacVinish LJ, Cuthbert AW, et al. Correction of the ion transport defect in cystic fibrosis transgenic mice by gene therapy. Nature 1993;362(6417):250-5.

[34] Davies JC, Alton EW. Gene therapy for cystic fibrosis. Proc Am Thorac Soc 2010;7(6): 408-14.

[35] Kollen WJ, Midoux P, Erbacher P, Yip A, Roche AC, Monsigny M, et al. Gluconoylated and glycosylated polylysines as vectors for gene transfer into cystic fibrosis airway epithelial cells. Hum Gene Ther 1996;7(13):1577-86.

[36] Parente RA, Nir S, Szoka FC, Jr. Mechanism of leakage of phospholipid vesicle contents induced by the peptide GALA. Biochemistry 1990;29(37):8720-8.

[37] Wagner E, Plank C, Zatloukal K, Cotten M, Birnstiel ML. Influenza virus hemagglutinin HA-2 N-terminal fusogenic peptides augment gene transfer by transferrin-polylysine-DNA complexes: toward a synthetic virus-like gene-transfer vehicle. Proc Natl Acad Sci U S A 1992;89(17):7934-8.

[38] Wyman TB, Nicol F, Zelphati O, Scaria PV, Plank C, Szoka FC, Jr. Design, synthesis, and characterization of a cationic peptide that binds to nucleic acids and permeabilizes bilayers. Biochemistry 1997;36(10):3008-17.

[39] Zauner W, Kichler A, Schmidt W, Mechtler K, Wagner E. Glycerol and polylysine synergize in their ability to rupture vesicular membranes: a mechanism for increased transferrin-polylysine-mediated gene transfer. Exp Cell Res 1997;232(1):137-45.

[40] Lam AP, Dean DA. Progress and prospects: nuclear import of nonviral vectors. Gene Ther 2010;17(4):439-47.

[41] Whittaker GR. Virus nuclear import. Adv Drug Deliv Rev 2003 Jun 16;55(6):733-47.

[42] Pollard H, Remy JS, Loussouarn G, Demolombe S, Behr JP, Escande D. Polyethylenimine but not cationic lipids promotes transgene delivery to the nucleus in mammalian cells. J Biol Chem 1998;273(13):7507-11.

[43] Escriou V, Carriere M, Scherman D, Wils P. NLS bioconjugates for targeting therapeutic genes to the nucleus. Adv Drug Deliv Rev 2003;55(2):295-306.

[44] Hebert E. Improvement of exogenous DNA nuclear importation by nuclear localization signal-bearing vectors: a promising way for non-viral gene therapy? Biol Cell 2003;95(2):59-68.

[45] Klink D, Schindelhauer D, Laner A, Tucker T, Bebok Z, Schwiebert EM, et al. Gene delivery systems--gene therapy vectors for cystic fibrosis. J Cyst Fibros 2004;3 Suppl 2:203-12. 
[46] Ferrari S, Griesenbach U, Geddes DM, Alton E. Immunological hurdles to lung gene therapy. Clin Exp Immunol 2003;132(1):1-8.

[47] Worgall S, Leopold PL, Wolff G, Ferris B, Van Roijen N, Crystal RG. Role of alveolar macrophages in rapid elimination of adenovirus vectors administered to the epithelial surface of the respiratory tract. Hum Gene Ther 1997;8(14):1675-84.

[48] Qin L, Ding Y, Pahud DR, Chang E, Imperiale MJ, Bromberg JS. Promoter attenuation in gene therapy: interferon-gamma and tumor necrosis factor-alpha inhibit transgene expression. Hum Gene Ther 1997;8(17):2019-29.

[49] Jooss K, Yang Y, Wilson JM. Cyclophosphamide diminishes inflammation and prolongs transgene expression following delivery of adenoviral vectors to mouse liver and lung. Hum Gene Ther 1996;7(13):1555-66.

[50] Hazinski TA, Ladd PA, DeMatteo CA. Localization and induced expression of fusion genes in the rat lung. Am J Respir Cell Mol Biol 1991;4(3):206-9.

[51] Kolb M, Inman M, Margetts PJ, Galt T, Gauldie J. Budesonide enhances repeated gene transfer and expression in the lung with adenoviral vectors. Am J Respir Crit Care Med 2001;164(5):866-72.

[52] Yang Y, Trinchieri G, Wilson JM. Recombinant IL-12 prevents formation of blocking IgA antibodies to recombinant adenovirus and allows repeated gene therapy to mouse lung. Nat Med 1995;1(9):890-3.

[53] Chirmule N, Raper SE, Burkly L, Thomas D, Tazelaar J, Hughes JV, et al. Readministration of adenovirus vector in nonhuman primate lungs by blockade of CD40-CD40 ligand interactions. J Virol 2000;74(7):3345-52.

[54] Chirmule N, Truneh A, Haecker SE, Tazelaar J, Gao G, Raper SE, et al. Repeated administration of adenoviral vectors in lungs of human CD4 transgenic mice treated with a nondepleting CD4 antibody. J Immunol 1999;163(1):448-55.

[55] Jooss K, Turka LA, Wilson JM. Blunting of immune responses to adenoviral vectors in mouse liver and lung with CTLA4Ig. Gene Ther 1998;5(3):309-19.

[56] Scaria A, St George JA, Gregory RJ, Noelle RJ, Wadsworth SC, Smith AE, et al. Antibody to CD40 ligand inhibits both humoral and cellular immune responses to adenoviral vectors and facilitates repeated administration to mouse airway. Gene Ther 1997;4(6):611-7.

[57] Hyde SC, Southern KW, Gileadi U, Fitzjohn EM, Mofford KA, Waddell BE, et al. Repeat administration of DNA/liposomes to the nasal epithelium of patients with cystic fibrosis. Gene Ther 2000;7(13):1156-65.

[58] Scheule RK, St George JA, Bagley RG, Marshall J, Kaplan JM, Akita GY, et al. Basis of pulmonary toxicity associated with cationic lipid-mediated gene transfer to the mammalian lung. Hum Gene Ther 1997;8(6):689-707. 
[59] Schwartz DA, Quinn TJ, Thorne PS, Sayeed S, Yi AK, Krieg AM. CpG motifs in bacterial DNA cause inflammation in the lower respiratory tract. J Clin Invest 1997;100(1): 68-73.

[60] Yew NS, Wang KX, Przybylska M, Bagley RG, Stedman M, Marshall J, et al. Contribution of plasmid DNA to inflammation in the lung after administration of cationic lipid:pDNA complexes. Hum Gene Ther 1999;10(2):223-34.

[61] Krieg AM. CpG motifs in bacterial DNA and their immune effects. Annu Rev Immunol 2002;20:709-60.

[62] Raper SE, Chirmule N, Lee FS, Wivel NA, Bagg A, Gao GP, et al. Fatal systemic inflammatory response syndrome in a ornithine transcarbamylase deficient patient following adenoviral gene transfer. Mol Genet Metab 2003;80(1-2):148-58.

[63] Cavazzana-Calvo M, Hacein-Bey S, de Saint Basile G, Gross F, Yvon E, Nusbaum P, et al. Gene therapy of human severe combined immunodeficiency (SCID)-X1 disease. Science 2000;288(5466):669-72.

[64] Hacein-Bey-Abina S, von Kalle C, Schmidt M, Le Deist F, Wulffraat N, McIntyre E, et al. A serious adverse event after successful gene therapy for X-linked severe combined immunodeficiency. N Engl J Med 2003;348(3):255-6.

[65] Hacein-Bey-Abina S, Von Kalle C, Schmidt M, McCormack MP, Wulffraat N, Leboulch $\mathrm{P}$, et al. LMO2-associated clonal $\mathrm{T}$ cell proliferation in two patients after gene therapy for SCID-X1. Science 2003;302(5644):415-9.

[66] Zhang Y, Chirmule N, Gao GP, Qian R, Croyle M, Joshi B, et al. Acute cytokine response to systemic adenoviral vectors in mice is mediated by dendritic cells and macrophages. Mol Ther 2001;3(5 Pt 1):697-707.

[67] Harvey BG, Leopold PL, Hackett NR, Grasso TM, Williams PM, Tucker AL, et al. Airway epithelial CFTR mRNA expression in cystic fibrosis patients after repetitive administration of a recombinant adenovirus. J Clin Invest 1999;104(9):1245-55.

[68] Zabner J, Ramsey BW, Meeker DP, Aitken ML, Balfour RP, Gibson RL, et al. Repeat administration of an adenovirus vector encoding cystic fibrosis transmembrane conductance regulator to the nasal epithelium of patients with cystic fibrosis. J Clin Invest 1996;97(6):1504-11.

[69] Croyle MA, Chirmule N, Zhang Y, Wilson JM. "Stealth" adenoviruses blunt cellmediated and humoral immune responses against the virus and allow for significant gene expression upon readministration in the lung. J Virol 2001;75(10):4792-801.

[70] Aitken ML, Moss RB, Waltz DA, Dovey ME, Tonelli MR, McNamara SC, et al. A phase I study of aerosolized administration of tgAAVCF to cystic fibrosis subjects with mild lung disease. Hum Gene Ther 2001;12(15):1907-16.

[71] Flotte TR, Zeitlin PL, Reynolds TC, Heald AE, Pedersen P, Beck S, et al. Phase I trial of intranasal and endobronchial administration of a recombinant adeno-associated 
virus serotype 2 (rAAV2)-CFTR vector in adult cystic fibrosis patients: a two-part clinical study. Hum Gene Ther 2003;14(11):1079-88.

[72] Moss RB, Milla C, Colombo J, Accurso F, Zeitlin PL, Clancy JP, et al. Repeated aerosolized AAV-CFTR for treatment of cystic fibrosis: a randomized placebo-controlled phase 2B trial. Hum Gene Ther 2007;18(8):726-32.

[73] Moss RB, Rodman D, Spencer LT, Aitken ML, Zeitlin PL, Waltz D, et al. Repeated adeno-associated virus serotype 2 aerosol-mediated cystic fibrosis transmembrane regulator gene transfer to the lungs of patients with cystic fibrosis: a multicenter, double-blind, placebo-controlled trial. Chest 2004;125(2):509-21.

[74] Wagner JA, Nepomuceno IB, Messner AH, Moran ML, Batson EP, Dimiceli S, et al. A phase II, double-blind, randomized, placebo-controlled clinical trial of tgAAVCF using maxillary sinus delivery in patients with cystic fibrosis with antrostomies. Hum Gene Ther 2002;13(11):1349-59.

[75] Griesenbach U, Alton EW. Gene transfer to the lung: lessons learned from more than 2 decades of CF gene therapy. Adv Drug Deliv Rev 2009 Feb 27;61(2):128-39.

[76] Al-Dosari MS, Gao X. Nonviral gene delivery: principle, limitations, and recent progress. AAPS J 2009;11(4):671-81.

[77] Dean DA, Machado-Aranda D, Blair-Parks K, Yeldandi AV, Young JL. Electroporation as a method for high-level nonviral gene transfer to the lung. Gene Ther 2003;10(18):1608-15.

[78] Xenariou S, Liang HD, Griesenbach U, Zhu J, Farley R, Somerton L, et al. Low-frequency ultrasound increases non-viral gene transfer to the mouse lung. Acta Biochim Biophys Sin (Shanghai) 2010;42(1):45-51.

[79] Xenariou S, Griesenbach U, Ferrari S, Dean P, Scheule RK, Cheng SH, et al. Using magnetic forces to enhance non-viral gene transfer to airway epithelium in vivo. Gene Ther 2006;13(21):1545-52.

[80] Tros de Ilarduya C, Sun Y, Duzgunes N. Gene delivery by lipoplexes and polyplexes. Eur J Pharm Sci 2010;40(3):159-70.

[81] Alton EW, Stern M, Farley R, Jaffe A, Chadwick SL, Phillips J, et al. Cationic lipidmediated CFTR gene transfer to the lungs and nose of patients with cystic fibrosis: a double-blind placebo-controlled trial. Lancet 1999;353(9157):947-54.

[82] Caplen NJ, Alton EW, Middleton PG, Dorin JR, Stevenson BJ, Gao X, et al. Liposomemediated CFTR gene transfer to the nasal epithelium of patients with cystic fibrosis. Nat Med 1995;1(1):39-46.

[83] Gill DR, Southern KW, Mofford KA, Seddon T, Huang L, Sorgi F, et al. A placebocontrolled study of liposome-mediated gene transfer to the nasal epithelium of patients with cystic fibrosis. Gene Ther 1997;4(3):199-209. 
[84] Porteous DJ, Dorin JR, McLachlan G, Davidson-Smith H, Davidson H, Stevenson BJ, et al. Evidence for safety and efficacy of DOTAP cationic liposome mediated CFTR gene transfer to the nasal epithelium of patients with cystic fibrosis. Gene Ther 1997;4(3):210-8.

[85] Ruiz FE, Clancy JP, Perricone MA, Bebok Z, Hong JS, Cheng SH, et al. A clinical inflammatory syndrome attributable to aerosolized lipid-DNA administration in cystic fibrosis. Hum Gene Ther 2001;12(7):751-61.

[86] Zabner J, Cheng SH, Meeker D, Launspach J, Balfour R, Perricone MA, et al. Comparison of DNA-lipid complexes and DNA alone for gene transfer to cystic fibrosis airway epithelia in vivo. J Clin Invest 1997;100(6):1529-37.

[87] Bushman F, Lewinski M, Ciuffi A, Barr S, Leipzig J, Hannenhalli S, et al. Genomewide analysis of retroviral DNA integration. Nat Rev Microbiol 2005;3(11):848-58.

[88] Perez-Luz S, Diaz-Nido J. Prospects for the use of artificial chromosomes and minichromosome-like episomes in gene therapy. J Biomed Biotechnol 2010;pii:642804..

[89] Ebersole TA, Ross A, Clark E, McGill N, Schindelhauer D, Cooke H, et al. Mammalian artificial chromosome formation from circular alphoid input DNA does not require telomere repeats. Hum Mol Genet 2000;9(11):1623-31.

[90] Grimes BR, Schindelhauer D, McGill NI, Ross A, Ebersole TA, Cooke HJ. Stable gene expression from a mammalian artificial chromosome. EMBO Rep 2001;2(10):910-4.

[91] Mejia JE, Larin Z. The assembly of large BACs by in vivo recombination. Genomics 2000 Dec 1;70(2):165-70.

[92] Heng HH, Goetze S, Ye CJ, Liu G, Stevens JB, Bremer SW, et al. Chromatin loops are selectively anchored using scaffold/matrix-attachment regions. J Cell Sci 2004;117(Pt 7):999-1008.

[93] Piechaczek C, Fetzer C, Baiker A, Bode J, Lipps HJ. A vector based on the SV40 origin of replication and chromosomal S/MARs replicates episomally in $\mathrm{CHO}$ cells. Nucleic Acids Res 1999;27(2):426-8.

[94] Papapetrou EP, Ziros PG, Micheva ID, Zoumbos NC, Athanassiadou A. Gene transfer into human hematopoietic progenitor cells with an episomal vector carrying an S/MAR element. Gene Ther 2006;13(1):40-51.

[95] Manzini S, Vargiolu A, Stehle IM, Bacci ML, Cerrito MG, Giovannoni R, et al. Genetically modified pigs produced with a nonviral episomal vector. Proc Natl Acad Sci U S A 2006;103(47):17672-7.

[96] Voigt K, Izsvak Z, Ivics Z. Targeted gene insertion for molecular medicine. J Mol Med (Berl) 2008;86(11):1205-19.

[97] Bertoni C, Jarrahian S, Wheeler TM, Li Y, Olivares EC, Calos MP, et al. Enhancement of plasmid-mediated gene therapy for muscular dystrophy by directed plasmid integration. Proc Natl Acad Sci U S A 2006;103(2):419-24. 
[98] Ivics Z, Izsvak Z. The expanding universe of transposon technologies for gene and cell engineering. Mob DNA 2010;1(1):25.

[99] Leblond AL, Naud P, Forest V, Gourden C, Sagan C, Romefort B, et al. Developing cell therapy techniques for respiratory disease: intratracheal delivery of genetically engineered stem cells in a murine model of airway injury. Hum Gene Ther 2009;20(11):1329-43.

[100] Abdallah BM, Kassem M. Human mesenchymal stem cells: from basic biology to clinical applications. Gene Ther 2008;15(2):109-16.

[101] Takahashi K, Tanabe K, Ohnuki M, Narita M, Ichisaka T, Tomoda K, et al. Induction of pluripotent stem cells from adult human fibroblasts by defined factors. Cell 2007;131(5):861-72.

[102] Yu J, Vodyanik MA, Smuga-Otto K, Antosiewicz-Bourget J, Frane JL, Tian S, et al. Induced pluripotent stem cell lines derived from human somatic cells. Science 2007;318(5858):1917-20.

[103] Aluigi M, Fogli M, Curti A, Isidori A, Gruppioni E, Chiodoni C, et al. Nucleofection is an efficient nonviral transfection technique for human bone marrow-derived mesenchymal stem cells. Stem Cells 2006;24(2):454-61.

[104] Wang G, Bunnell BA, Painter RG, Quiniones BC, Tom S, Lanson NA, Jr., et al. Adult stem cells from bone marrow stroma differentiate into airway epithelial cells: potential therapy for cystic fibrosis. Proc Natl Acad Sci U S A 2005;102(1):186-91.

[105] Conese M, Ascenzioni F, Boyd AC, Coutelle C, De Fino I, De Smedt S, et al. Gene and cell therapy for cystic fibrosis: from bench to bedside. J Cyst Fibros 2011;10 Suppl 2:S114-28.

[106] Gan KH, Veeze HJ, van den Ouweland AM, Halley DJ, Scheffer H, van der Hout A, et al. A cystic fibrosis mutation associated with mild lung disease. N Engl J Med 1995;333(2):95-9.

[107] Johnson LG, Boyles SE, Wilson J, Boucher RC. Normalization of raised sodium absorption and raised calcium-mediated chloride secretion by adenovirus-mediated expression of cystic fibrosis transmembrane conductance regulator in primary human cystic fibrosis airway epithelial cells. J Clin Invest 1995;95(3):1377-82.

[108] Zhang L, Button B, Gabriel SE, Burkett S, Yan Y, Skiadopoulos MH, et al. CFTR delivery to $25 \%$ of surface epithelial cells restores normal rates of mucus transport to human cystic fibrosis airway epithelium. PLoS Biol 2009;7(7):e1000155.

[109] Crawford I, Maloney PC, Zeitlin PL, Guggino WB, Hyde SC, Turley H, et al. Immunocytochemical localization of the cystic fibrosis gene product CFTR. Proc Natl Acad Sci U S A 1991;88(20):9262-6.

[110] Trezise AE, Chambers JA, Wardle CJ, Gould S, Harris A. Expression of the cystic fibrosis gene in human foetal tissues. Hum Mol Genet 1993;2(3):213-8. 
[111] Smith AN, Wardle CJ, Harris A. Characterization of DNASE I hypersensitive sites in the $120 \mathrm{~kb} 5$ ' to the CFTR gene. Biochem Biophys Res Commun 1995;211(1):274-81.

[112] Smith AN, Barth ML, McDowell TL, Moulin DS, Nuthall HN, Hollingsworth MA, et al. A regulatory element in intron 1 of the cystic fibrosis transmembrane conductance regulator gene. J Biol Chem 1996;271(17):9947-54.

[113] Smith DJ, Nuthall HN, Majetti ME, Harris A. Multiple potential intragenic regulatory elements in the CFTR gene. Genomics 2000;64(1):90-6.

[114] Nuthall HN, Moulin DS, Huxley C, Harris A. Analysis of DNase-I-hypersensitive sites at the 3' end of the cystic fibrosis transmembrane conductance regulator gene (CFTR). Biochem J 1999;341 ( Pt 3):601-11.

[115] Nuthall HN, Vassaux G, Huxley C, Harris A. Analysis of a DNase I hypersensitive site located -20.9 kb upstream of the CFTR gene. Eur J Biochem 1999;266(2):431-43.

[116] Phylactides M, Rowntree R, Nuthall H, Ussery D, Wheeler A, Harris A. Evaluation of potential regulatory elements identified as DNase I hypersensitive sites in the CFTR gene. Eur J Biochem 2002;269(2):553-9.

[117] Rowntree RK, Vassaux G, McDowell TL, Howe S, McGuigan A, Phylactides M, et al. An element in intron 1 of the CFTR gene augments intestinal expression in vivo. Hum Mol Genet 2001;10(14):1455-64.

[118] Kotzamanis G, Abdulrazzak H, Gifford-Garner J, Haussecker PL, Cheung W, GrillotCourvalin $\mathrm{C}$, et al. CFTR expression from a BAC carrying the complete human gene and associated regulatory elements. J Cell Mol Med 2009;13(9A):2938-48.

[119] Zabner J, Couture LA, Gregory RJ, Graham SM, Smith AE, Welsh MJ. Adenovirusmediated gene transfer transiently corrects the chloride transport defect in nasal epithelia of patients with cystic fibrosis. Cell 1993;75(2):207-16.

[120] Wagner JA, Messner AH, Moran ML, Daifuku R, Kouyama K, Desch JK, et al. Safety and biological efficacy of an adeno-associated virus vector-cystic fibrosis transmembrane regulator (AAV-CFTR) in the cystic fibrosis maxillary sinus. Laryngoscope 1999;109(2 Pt 1):266-74.

[121] Sorscher EJ, Logan JJ, Frizzell RA, Lyrene RK, Bebok Z, Dong JY, et al. Informed consent to participate in a research study -- gene therapy for cystic fibrosis using cationic liposome mediated gene transfer: a phase I trial of safety and efficacy in the nasal airway. Hum Gene Ther 1994;5(10):1271-7.

[122] Crystal RG, McElvaney NG, Rosenfeld MA, Chu CS, Mastrangeli A, Hay JG, et al. Administration of an adenovirus containing the human CFTR cDNA to the respiratory tract of individuals with cystic fibrosis. Nat Genet 1994;8(1):42-51.

[123] Boucher RC, Knowles MR, Johnson LG, Olsen JC, Pickles R, Wilson JM, et al. Gene therapy for cystic fibrosis using E1-deleted adenovirus: a phase I trial in the nasal 
cavity. The University of North Carolina at Chapel Hill. Hum Gene Ther 1994;5(5): 615-39.

[124] Knowles MR, Hohneker KW, Zhou Z, Olsen JC, Noah TL, Hu PC, et al. A controlled study of adenoviral-vector-mediated gene transfer in the nasal epithelium of patients with cystic fibrosis. N Engl J Med 1995;333(13):823-31.

[125] Hay JG, McElvaney NG, Herena J, Crystal RG. Modification of nasal epithelial potential differences of individuals with cystic fibrosis consequent to local administration of a normal CFTR cDNA adenovirus gene transfer vector. Hum Gene Ther 1995;6(11):1487-96.

[126] Bellon G, Michel-Calemard L, Thouvenot D, Jagneaux V, Poitevin F, Malcus C, et al. Aerosol administration of a recombinant adenovirus expressing CFTR to cystic fibrosis patients: a phase I clinical trial. Hum Gene Ther 1997;8(1):15-25.

[127] Noone PG, Hohneker KW, Zhou Z, Johnson LG, Foy C, Gipson C, et al. Safety and biological efficacy of a lipid-CFTR complex for gene transfer in the nasal epithelium of adult patients with cystic fibrosis. Mol Ther 2000;1(1):105-14.

[128] Zuckerman JB, Robinson CB, McCoy KS, Shell R, Sferra TJ, Chirmule N, et al. A phase I study of adenovirus-mediated transfer of the human cystic fibrosis transmembrane conductance regulator gene to a lung segment of individuals with cystic fibrosis. Hum Gene Ther 1999;10(18):2973-85.

[129] Joseph PM, O'Sullivan BP, Lapey A, Dorkin H, Oren J, Balfour R, et al. Aerosol and lobar administration of a recombinant adenovirus to individuals with cystic fibrosis. I. Methods, safety, and clinical implications. Hum Gene Ther 2001;12(11):1369-82.

[130] Perricone MA, Morris JE, Pavelka K, Plog MS, O'Sullivan BP, Joseph PM, et al. Aerosol and lobar administration of a recombinant adenovirus to individuals with cystic fibrosis. II. Transfection efficiency in airway epithelium. Hum Gene Ther 2001;12(11): 1383-94. 